Article

\title{
The Link between Permeable Interlocking Concrete Pavement (PICP) Design and Nutrient Removal
}

\author{
Bodi Kimberly Liu@ and Neil P. Armitage* \\ Department of Civil Engineering, University of Cape Town, Private Bag X3, Rondebosch 7701, South Africa; \\ lxxbod001@myuct.ac.za \\ * Correspondence: Neil.Armitage@uct.ac.za; Tel.: +27-21-650-2589
}

Received: 26 May 2020; Accepted: 11 June 2020; Published: 16 June 2020

\begin{abstract}
The construction of 'hard' impermeable surfaces in urban areas results in the increased flow of stormwater runoff and its associated pollutants into downstream receiving waters. Permeable Pavement Systems (PPS) can help mitigate this. The most common type of PPS in South Africa is permeable interlocking concrete pavement (PICP), but there is currently insufficient information available on the relative treatment performance of different PICP designs. This paper describes an investigation into the performance of ten different PICP systems constructed in the Civil Engineering Laboratory at the University of Cape Town for the treatment of various nutrients commonly found in stormwater runoff. It was found that removal efficiencies ranged from $27.5 \%$ to $78.7 \%$ for ammonia-nitrogen and from $-37 \%$ to $11 \%$ for orthophosphate-phosphorus; whilst $4 \%$ to $20.2 \%$ more nitrite-nitrogen and $160 \%$ to $2580 \%$ more nitrate-nitrogen were simultaneously added. The presence of a geotextile resulted in higher ammonia-nitrogen removal efficiencies but also higher nitrate-nitrogen addition than those cells without-with small differences between various types. The cell with a permanently wet 'sump' had the highest nitrate-nitrogen addition of all. Lower $\mathrm{pH}$ results in higher nitrate-nitrogen concentrations, whilst the electrical conductivity strongly depends on the length of the periods between rainfall 'seasons', decreasing rapidly during wet periods but increasing during dry periods. Paver type also had a minor impact on nutrient removal.
\end{abstract}

Keywords: permeable interlocking concrete pavement (PICP); nutrient removal from stormwater; sustainable drainage systems (SuDS)

\section{Introduction}

Rapid urbanization in the 21st century has resulted in much land becoming impervious owing to the construction of roads, parking lots, driveways, and buildings. The traditional approach to urban drainage is to convey stormwater runoff in pipe and canal networks to the nearest receiving water bodies as quickly as possible. This, however, leads to increased runoff flows and volumes resulting in the erosion of watercourses whilst stormwater pollutants, such as heavy metals, hydrocarbons from motor vehicles, suspended solids, and nutrients, such as nitrogen and phosphorus, cause a deterioration in water quality. There has been reduced groundwater recharge leading to the dropping of groundwater tables in some areas [1-4].

In many countries, including South Africa, a more sustainable approach for stormwater management termed Sustainable Drainage Systems (SuDS)—called Low Impact Development (LID) in the USA and Water Sensitive Urban Design (WSUD) in Australia-has emerged [3]. As one of the source controls in SuDS, permeable pavement systems (PPS) offer a potential solution to the problem of increased surface runoff and decreased stream water quality by promoting the infiltration of stormwater runoff through the wearing course and some treatment through the underlying aggregate layers [5]. PPS can be adapted to make an effective stormwater harvesting and storage device for 
fit-for-purpose water re-use [6,7]. Permeable interlocking concrete pavers (PICP) are the most widely used PPS internationally [8]. They comprise of impervious paving blocks with small permeable joints filled with a suitable pea-sized ( $2-5 \mathrm{~mm}$ ) aggregate (typically ASTM Nos. 8, 89, or 9) accounting for $5 \%$ to $15 \%$ of the paver surface area. These joints allow surface water to infiltrate into the pavement structure $[9,10]$. Below the paving surface is an open-graded bedding layer of a small-sized aggregate such as that used between the pavers. The bedding layer may be separated from the lower layers by a geotextile-although this is controversial. The geotextile is used to prevent the entrance of fine sediments into the PICP structure and/or provide an environment for bacteria to remove pollutants $[6,11,12]$. Below the bedding layer and geotextile (if present) is a sub-base consisting of an open-graded 20-63 mm aggregate (typically ASTM Nos. 2, 3, or 4). Apart from its usual role in supporting and distributing vehicle loads, this open-graded sub-base acts as a reservoir temporarily detaining runoff before slow release through an underdrain or into permeable underlying soils. It also acts as a pollutant trap. The relatively rapid rate of draining usually keeps the sub-base in an aerobic state suitable for nitrification [13].

Total suspended solids (TSS), phosphate, ammonia, and nitrate are common pollutants in stormwater, and many studies, e.g., Collins et al. [14], Drake [15], Huang [16], as well as Tota-Maharaj and Scholz [17], have attempted to quantitively assess the treatment performance of PPS in removing them. This appears to depend on various factors such as the type of pavers, the size and condition of the stone aggregates, the type and location of any geotextile, the type of outlet, and the period between rain events-but not enough is known about the relative performance of different PICP designs, particularly as constructed. With respect to construction, the treatment performance of PICP can be adversely affected by the use of unwashed aggregates in the PICP structure [18]; however, most PICP installations in South Africa are constructed with unwashed aggregates. There is a difference of opinion regarding the use of geotextiles in the PICP structure with some studies suggesting that the presence of geotextile has an adverse effect on the stormwater performance due to clogging [19], while others recommend its use for the purposes of water quality improvement and maintain that it has no impact on clogging [20,21]. Collins et al. [14] and Drake [15] evaluated the impact of a submerged zone on nitrogen removal in PICP but there does not appear to be universal agreement on its benefits.

Dealing with the primary removal mechanisms in turn:

- TSS is primarily removed through mechanical filtration through the surface and base layers of the PPS and through sedimentation [19]. It is efficiently removed $(>80 \%)$ by various PPS [22-25];

- The Total Phosphorous (TP) removal mechanisms are primarily chemical sorption and biological activity [26]. Its removal efficiency thus depends on the adsorption capacity of granular material within the PICP and the amount of time for various biogeochemical processes to take place. Many studies have found PICP to be effective in removing TP $[17,24]$, for example, Ball and Rankin [27] found TP removal of more than 70\%. However, Brown and Borst [13] found phosphate concentrations in PICP and Porous Concrete (PC) effluents that were significantly larger than that in the influents which suggests that phosphate was leaching from their two sites and recommended further studies to determine the cause of phosphate leaching;

- According to Huang et al. [16], Total Nitrogen (TN) is thought to be removed by the biological processes that take place in the void space of pavement structures that are largely associated with the growth of biofilm which in turn is highly dependent on temperature [17,20]. Huang et al. [28], however, considered that the environment of the pavement structure may not be suitable for bio-film growth and thus PICP may not be very effective in removing TN [29]. Collins et al. [30] showed that the anoxic conditions for denitrification and subsequent nitrogen removal may not develop in many fast-draining, infiltration-oriented Stormwater Control Measures (SCMs) such as PICP. Ammonium-nitrogen can be adsorbed to negatively charged sites on the filter material and then be removed with the sediments, but Collins et al. [30] describes the primary nitrogen transformation process in PICP as nitrification and filtration of particulate-bound nitrogen as well as denitrification through an internal anoxic zone-if there is one. Tota-Maharaj and 
Scholz [17] consider that the nutrient removal process in PICP is mainly due to processes such as nitrification and denitrification as well as biogeochemical degradation, and these processes will occur predominantly in the wet lower sub-base of the PICP. Collins et al. [14] and Drake et al. [31] both found the ammonia/ammonium and Total Kjeldahl Nitrogen (TKN) effluent concentrations from PICP were significantly lower than impervious asphalt runoff concentrations, however, they also both found that the combined nitrite and nitrate concentrations were significantly higher than those in impervious asphalt runoff, which might be due to nitrification of ammonia/ammonium in the PICP. Bean et al. [24] also found that the nitrate and nitrite concentration is higher in the PICP exfiltrate than in impervious asphalt runoff. Drake [15] evaluated the water quality from partial-infiltration PPS (PICP and PC) having temporary saturated zones favourable for denitrification after moderate and large rainfall (i.e., $>7 \mathrm{~mm}$ ), however, the nitrate concentrations in the effluent were still larger than in the impervious asphalt runoff. Collins et al. [14] found that a PICP section with an inadvertent sump discharged significantly larger nitrate and nitrite concentrations than all other PPS tested. Roseen et al. [32] found that the mean dissolved inorganic nitrogen concentrations (ammonia/ammonium, nitrate, and nitrate) in the effluent from a porous asphalt (PA) site in New Hampshire were 35\% higher than the concentrations in the associated impervious asphalt runoff. Collins et al. [29] note that the microbial denitrification process is favoured under anoxic conditions and is driven by electron donors such as carbon, iron, or sulphur;

- Many studies have investigated the impact of a geotextile placed immediately under the bedding layer in PPS on the removal efficiency of heavy metals, oil, and suspended solids, but very few on nutrient removal [33]. Tota-Maharaj and Scholz [17] showed that most of the microbial activity takes place in the vicinity of the geotextile; its presence helps to keep the nitrate-nitrogen concentration and suspended solids low. Zhao et al. [34] found that non-woven geotextile membranes provided better hydraulic properties and pollutant removal performance in PA than when no geotextile was present. Mullaney et al. [32] found that PICP test rigs with an upper-level geotextile had higher removal rates for cadmium, lead, and zinc than those without.

In a bid to understand the relative impact of different designs on PICP water quality improvement, this research investigated the relative impact of different types of pavers, the presence or absence of a geotextile, the use of washed and unwashed aggregates, and the incorporation of a permanent wet zone in PICP on the removal of TSS and various nutrients (nitrate, nitrite, ammonia and orthophosphate) commonly found in stormwater runoff, together with the changes in electroconductivity (EC) and $\mathrm{pH}$. This was determined via controlled laboratory-based experiments with limited verification provided by water quality measurements carried out on a nearby parking area constructed with PICP-something that has seldom been done in previous studies.

\section{Materials and Methods}

\subsection{Lab-Scale Test Cells}

The laboratory-based experiments were conducted on ten different PICP systems installed in specially constructed test 'cells' in the Civil Engineering Laboratory at the University of Cape Town (UCT) (Figure 1). Each cell comprised a polyethylene (HDPE) plastic container $1200 \mathrm{~mm}$ long, $1100 \mathrm{~mm}$ wide, and $400 \mathrm{~mm}$ deep, fitted with a perforated under-drain with the outflow controlled by a valve on the outlet. The experimental cells generally were filled with a $250 \mathrm{~mm}$ sub-base layer of 50-63 mm aggregate at the bottom, upon which was placed a $100 \mathrm{~mm}$ base layer of $19-25 \mathrm{~mm}$ aggregate, a $50 \mathrm{~mm}$ layer of 2-6 mm bedding gravel, then finally various proprietary pavers with 'pea-sized' gravel (2-4 mm quartzite/gritstone) placed in between them to provide a flow-path for the surface water. Some cells had a geotextile between the base and bedding layers while others did not. In some cells, the aggregate was carefully washed by hand with a brush before installation; others were not. One cell had a raised outlet to create a permanent wet 'sump' at the bottom of the cell. Figure 2 shows a typical cross-section through the PICP cells whilst Table 1 describes the individual cell designs. 


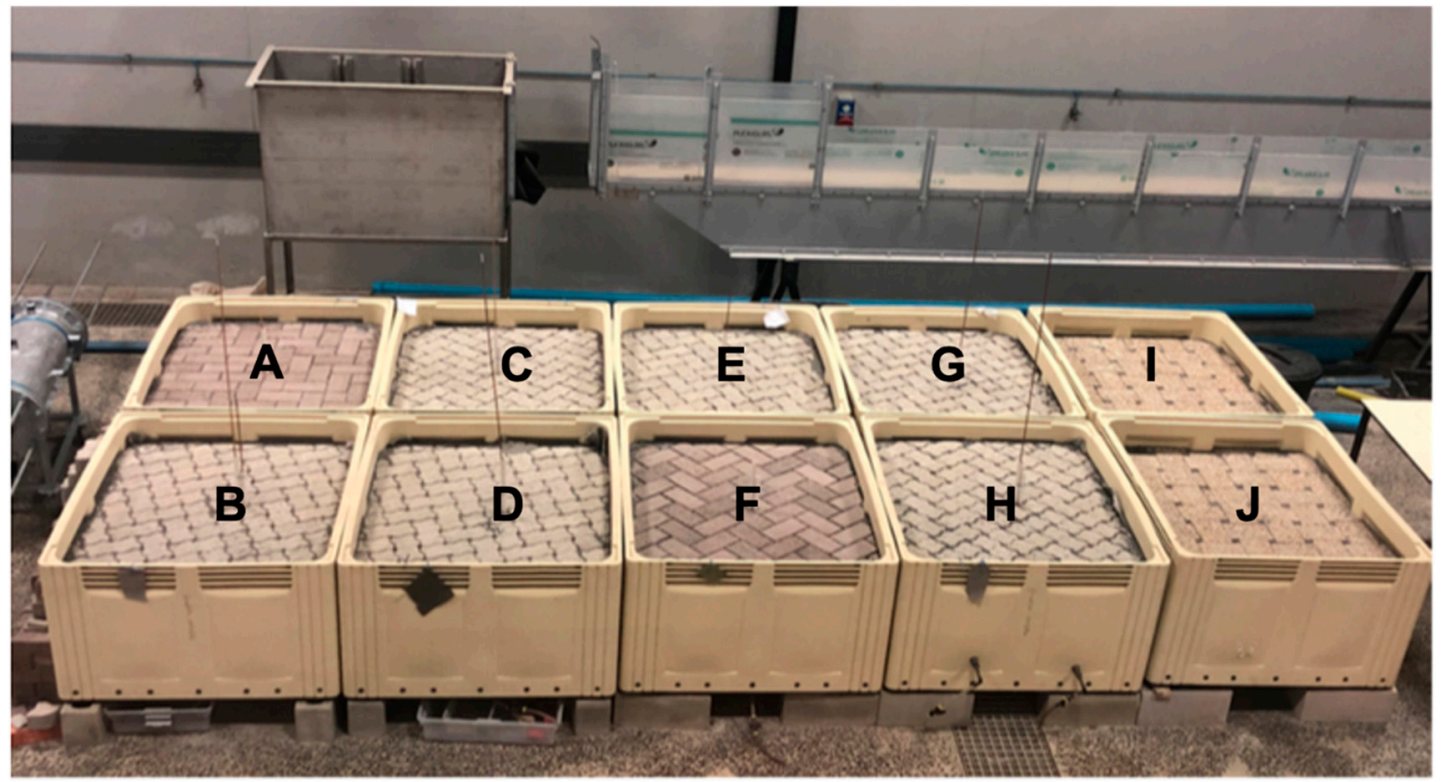

Figure 1. Permeable interlocking concrete pavement (PICP) test cells (Cell A and Cell $\mathrm{F}$ laid with Aquaflow ${ }^{\circledR}$ pavers, Cell B, C, D, E, G, H laid with Permealock ${ }^{\circledR}$ pavers, and Cell I and Cell J laid with 'traditional' exposed pavers).

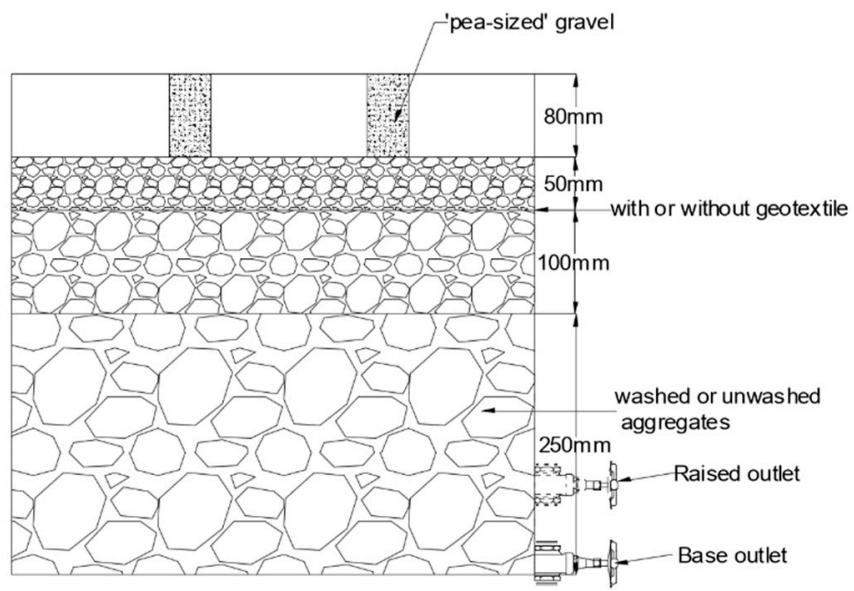

Figure 2. Typical cross-section of the permeable interlocking concrete pavement (PICP) test cells.

Table 1. Permeable interlocking concrete pavement (PICP) test cell description.

\begin{tabular}{ccccc}
\hline Cell & Pavers & Geotextile & Aggregate Component & Outlet \\
\hline A & Aquapave $^{\circledR}$ & None & Washed & Base outlet \\
B & Permealock & Fibertex & Unwashed & Base outlet \\
C & Permealock & Fibertex & Washed & Base outlet \\
D & Permealock & Kaytech bidim & Washed & Base outlet \\
E & Permealock & None & Washed & Base outlet \\
F & Aquapave ${ }^{\circledR}$ & Inbitex & Washed & Base outlet \\
G & Permealock & None & Unwashed & Base outlet \\
H & Permealock & Fibertex & Unwashed & Raised outlet \\
I & Exposed pavers & Fibertex & Washed & Base outlet \\
J & Exposed pavers & None & Washed & Base outlet \\
\hline
\end{tabular}




\subsection{Types of Pavers}

Three types of pavers were laid in the PICP experimental cells. They were Aquaflow ${ }^{\circledR}$ and Permealock ${ }^{\circledR}$ pavers both especially designed for PICP, as well as standard exposed aggregate pavers laid to create gaps for the water to infiltrate through. The Aquaflow ${ }^{\circledR}$ pavers were $200 \times 100 \times 80 \mathrm{~mm}$ and had a chamfered slot that provide a passage for the water [35]. The Permealock ${ }^{\circledR}$ pavers were $203 \times 102 \times 80 \mathrm{~mm}$ and were provided with 12 protrusions to separate the pavers from each other for water ingress [36]. The standard exposed aggregate pavers were $200 \times 100 \times 70 \mathrm{~mm}$. Figure 3 shows how the three types of pavers were laid for the PICP test cells.

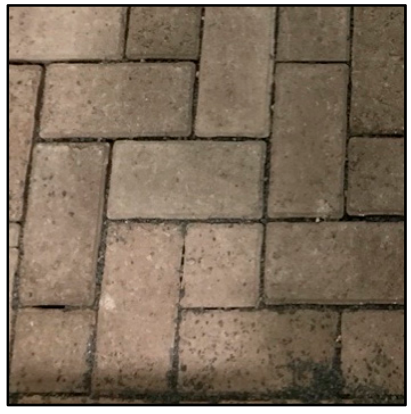

(a)

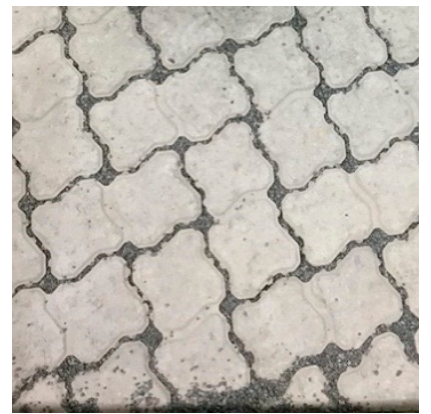

(b)

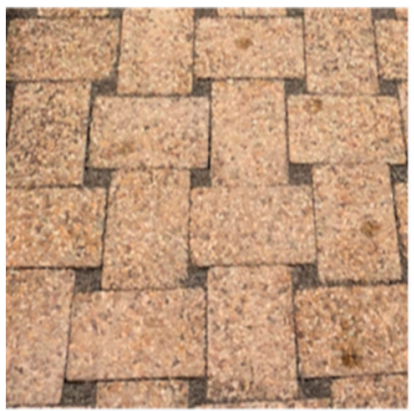

(c)

Figure 3. Paver types: (a) Aquaflow ${ }^{\circledR}$; (b) Permealock ${ }^{\circledR}$; and (c) standard exposed aggregate.

\subsection{Types of Geotextile}

Three types of geotextile were used in the PICP experimental cells: Fibertex ${ }^{\circledR}$ (non-woven), Kaytech bidim ${ }^{\circledR}$ (non-woven), and Inbitex (non-woven) [37-39] (Table 1).

\subsection{Comparison of Design Features}

The impact of each design feature (type of paver, presence or absence of a geotextile of one of three types, the use of washed and unwashed aggregates (the washing taking place in the laboratory during PICP construction), and the presence or absence of a permanently wet zone) could be determined by comparing those PICP cells having one different design feature holding all other design features constant (Table 2).

Table 2. Determination of the impact of different criteria.

\begin{tabular}{|c|c|c|c|}
\hline Criteria & \multicolumn{3}{|c|}{ Different Cells Comparison } \\
\hline Impact of types of pavers & \multicolumn{3}{|c|}{$\begin{array}{c}\left.\text { Cell A and Cell E (Aquaflow }{ }^{\circledR} \text { versus Permealock }{ }^{\circledR}\right) ; \text { Cell E and Cell J (Permealock }{ }^{\circledR} \text { versus } \\
\text { exposed aggregate); Cell A and Cell J (Aquaflow }{ }^{\circledR} \text { versus exposed aggregate) }\end{array}$} \\
\hline Impact of geotextile & $\begin{array}{l}\text { Cell A (no geotextile) and } \\
\text { Cell F (Inbitex }{ }^{\circledR} \text { geotextile) }\end{array}$ & $\begin{array}{c}\text { Cell E (no geotextile) and } \\
\text { Cell C (Fibertex }{ }^{\circledR} \text { geotextile) } \\
\text { and Cell D } \\
\text { (Kaytech bidim }{ }^{\circledR} \text { geotextile) }\end{array}$ & $\begin{array}{l}\text { Cell G/Cell J (no geotextile) } \\
\text { and Cell B/Cell I } \\
\text { (Fibertex }{ }^{\circledR} \text { geotextile) }\end{array}$ \\
\hline Types of geotextile & \multicolumn{3}{|c|}{ Cell C and Cell D (Fibertex ${ }^{\circledR}$ versus Kaytech bidim ${ }^{\circledR}$ ) } \\
\hline $\begin{array}{l}\text { Impact of raised outlet } \\
\text { (submerged zone) }\end{array}$ & \multicolumn{3}{|c|}{ Cell B (base outlet) and Cell H (raised outlet) } \\
\hline $\begin{array}{l}\text { Impact of } \\
\text { unwashed aggregates }\end{array}$ & \multicolumn{3}{|c|}{ Cell B (unwashed stones) and Cell C (washed stones) } \\
\hline
\end{tabular}

\subsection{Field Test Study Area}

Field testing was carried out on the New Engineering Building (NEB) parking lot located on the UCT upper campus in a bid to verify the laboratory investigations in a more realistic setting.

The NEB parking area was constructed in 2014 and is divided into three separate sections by ground beams (Figure 4). This was necessary due to the slope of the site, however, it provided an 
opportunity for its use as a test site for the long-term monitoring of the PICP. The highest-lying section (NEB-I) of the pavement includes an area that was sealed off to provide surface runoff for comparison with the drainage from the other two sections. The middle section (NEB-B) is a conventional PICP installation with an Inbitex geotextile installed between the bedding material and the underlying aggregate. The lowest section (NEB-A) uses the same design as the middle section, but without the presence of the geotextile. Monitoring chambers were installed at the underdrain outlets to each section to allow for water quality testing.

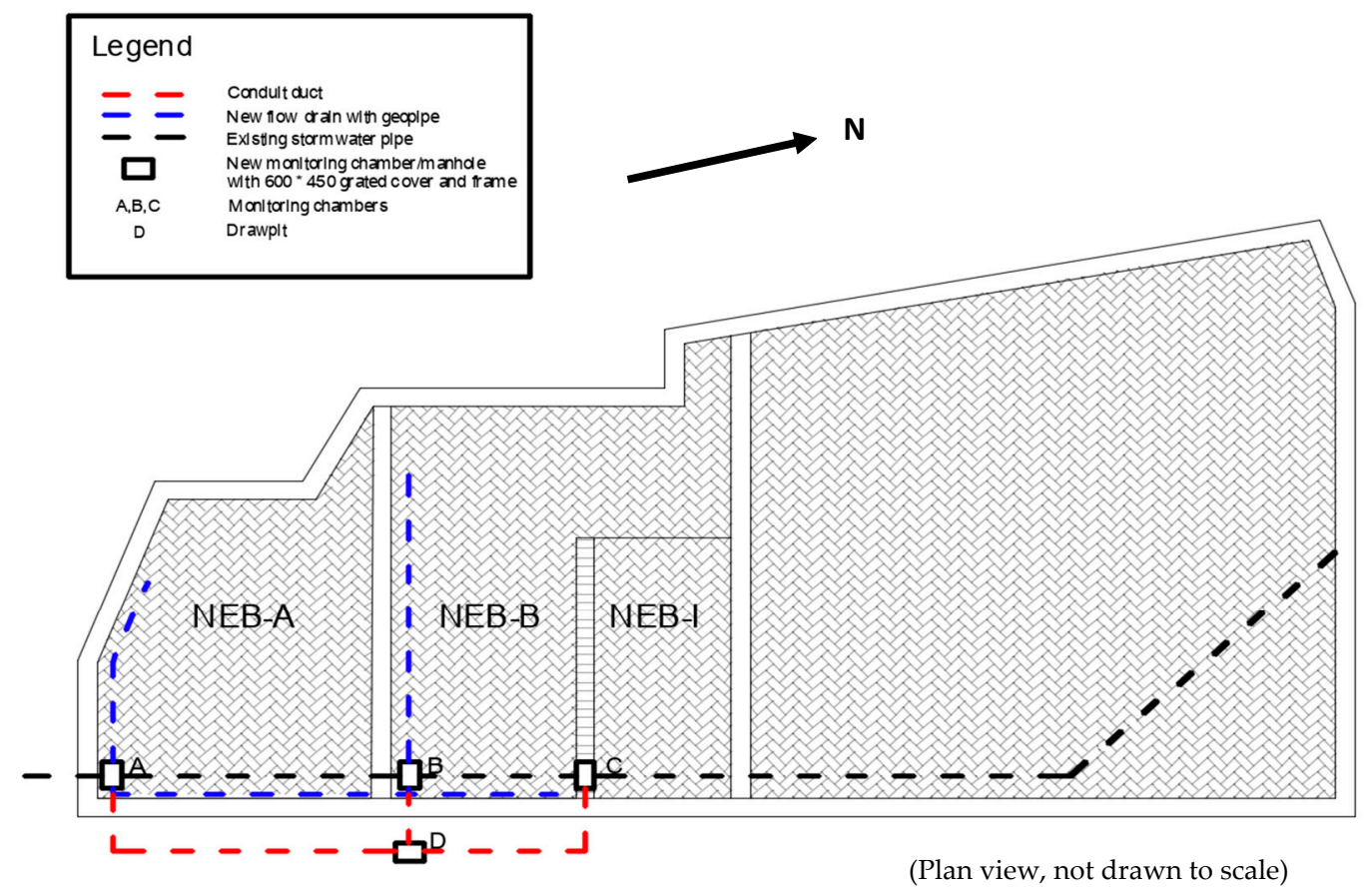

Figure 4. Schematic plan of the New Engineering Building (NEB) parking lot showing the drainage system and monitoring chambers [18].

\subsection{Test Procedure}

The research followed the following steps:

1. Infiltration tests were carried out to determine the infiltration rate of each PICP test cell with the use of a single ring infiltrometer following the test procedure given by the ASTM C1781: Standard Test Method for surface infiltration rate of permeable unit pavement systems [40];

2. Each test cell was given an initial flush of 10-liter of clean potable tap water applied with a watering can. The outflow from each cell was tested to determine the 'base-line' water quality prior to the addition of any external pollutants. The $\mathrm{pH}$, temperature, and EC of the water discharging from the bottom of each PICP cell were measured in-situ using hand-held probes. Grab samples were analyzed in the water quality lab for TSS, orthophosphate-phosphorus, ammonia-nitrogen, nitrite-nitrogen, and nitrate-nitrogen;

3. Each PICP cell was then subjected to multiple 'seasons' of accelerated rainfall events using pre-prepared synthetic stormwater containing suitable soluble pollutants to test their treatment efficacy. The synthetic stormwater testing was carried out in two distinct phases. In the first phase, three rainfall seasons were simulated in October 2017, September 2018, and April 2019, respectively, using water containing the commercial fertilizer 'Growing Orchid' at an appropriate concentration as the pollutant. Each season comprised nine distinct 'storm' events that were applied one per day using a 10-liter watering can onto the surface of experimental cells, with each PICP cell receiving the same volume of water. The $\mathrm{pH}$, temperature, and EC of the outflow 
were determined for each PICP cell for each rainfall event. Samples were analyzed in the water laboratory on the first, fifth, and ninth day for the concentrations of ammonia-nitrogen, nitrite-nitrogen, nitrate-nitrogen, and orthophosphate-phosphorus;

4. The second phase of the research took place in August-September 2019. The use of 'Growing Orchid' [40] as the source of stormwater contamination was abandoned because of problems with inconsistent nitrogen to phosphorus ratios giving rise to inconsistent influent quality-and thus, potentially outflow quality. Synthetic stormwater was thus produced in the laboratory by adding $\mathrm{NH}_{4} \mathrm{Cl}, \mathrm{K}_{2} \mathrm{H}_{2} \mathrm{PO}_{4}$, and $\mathrm{KNO}_{3}$ to tap water in carefully measured quantities in a 500-liter tank. It was applied using a 10-litre watering can as before (Figure 5). Furthermore, instead of applying stormwater for nine consecutive days without any break-thus, ignoring the possible impact of dry periods between rainfall events-a new rainfall regime was purposed with intermittent dry and wet periods to represent the four months of the 'typical' Cape Town rainy season-but in an accelerated 1.5 month period (Table 3). The $\mathrm{pH}$, temperature, and EC of the outflows from each cell were measured daily, whilst samples were analyzed in the water quality laboratory for ammonia-nitrogen, nitrite-nitrogen, nitrate-nitrogen, and orthophosphate-phosphorus on a weekly basis;

5. The flow over and through the NEB parking area was tested during four significant storm events (i.e., $>7 \mathrm{~mm}$ ) between 2018 and 2019. The $\mathrm{pH}$, temperature, and EC were tested in-situ using hand-held probes; grab samples were then taken to the water quality laboratory for measurement of the ammonia-nitrogen, nitrate-nitrogen, nitrite-nitrogen, and orthophosphate-phosphorus concentrations.

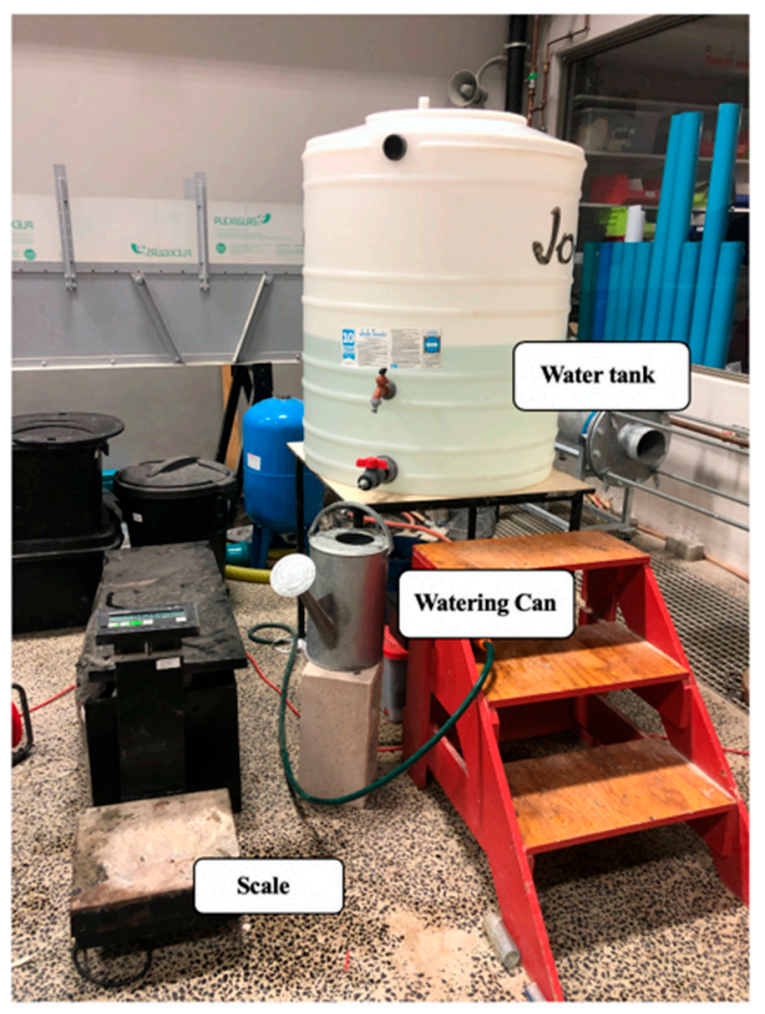

Figure 5. A 500-litre water tank and scale for measuring the mass of the liquid in the watering can. 
Table 3. August-September 2019 rainfall test schedule (the numbers in bold indicate the day of the month whilst the numbers in brackets give the rainfall volume (litres) applied to each PICP cell).

\begin{tabular}{|c|c|c|c|c|c|c|}
\hline \multicolumn{7}{|c|}{ August } \\
\hline$S$ & $\mathbf{M}$ & $\mathrm{T}$ & $\mathbf{W}$ & $T$ & $\mathbf{F}$ & S \\
\hline & & & & 1 & 2 & 3 \\
\hline 4 & $5(0)$ & $6(23)$ & $7(0)$ & $8(0)$ & $9(0)$ & $10(0)$ \\
\hline $11(0)$ & $12(28)$ & $13(10)$ & $14(13)$ & $15(15)$ & $16(14)$ & $17(33)$ \\
\hline $18(0)$ & $19(7)$ & $20(10)$ & $21(0)$ & $22(0)$ & $23(14)$ & $24(28)$ \\
\hline \multicolumn{7}{|c|}{ September } \\
\hline $\mathbf{1}(0)$ & $2(37)$ & $3(38)$ & $4(0)$ & $5(10)$ & $6(0)$ & $7(0)$ \\
\hline $8(17)$ & $9(0)$ & $10(0)$ & $11(0)$ & $12(7)$ & $13(0)$ & $14(40)$ \\
\hline
\end{tabular}

\subsection{Analytical Methods}

The following analytical methods were used:

- $\quad$ The $\mathrm{pH}$, temperature, and EC were measured at the outlets of the cells using OHAUS ${ }^{\circledR}$ ST20 pH-temperature and OHAUS ${ }^{\circledR}$ ST20 C-B EC-temperature probes;

- All the other parameters were determined from grab samples analysed in the Civil Engineering Water Quality Laboratory. The TSS was measured following US EPA Method 160.2: Total Suspended Solids (TSS) [41]. Thereafter, a Thermo Scientific ${ }^{\mathrm{TM}}$ Gallery ${ }^{\mathrm{TM}}$ Discrete Analyzer [42] was used to measure the concentrations of ammonia-nitrogen, nitrate-nitrogen, nitrite-nitrogen, and orthophosphate-phosphorus through an automated photometric (colorimetric and enzymatic) analysis. If the samples were not to be tested immediately, they were stored in a fridge (at $3{ }^{\circ} \mathrm{C}$ to $5^{\circ} \mathrm{C}$ ) to minimize bacterial activity and phytoplankton growth.

\section{Results and Discussion}

\subsection{Infiltration Test Results}

The infiltration rates for all ten experimental cells were uniformly high-ranging between 9900 and $17,600 \mathrm{~mm} / \mathrm{h}$, however this will not be discussed here as they merely proved the excellent performance of the PICP cells and are unlikely to have any impact on the nutrient removal.

\subsection{Clean Water Test Results}

The clean water test results show all ten PICP cells introduced pollutants (ammonia-nitrogen, orthophosphate-phosphorus, nitrite-nitrogen, and nitrate-nitrogen) to the system, and these added pollutants were assumed to come from the aggregate layers in the PICP system (Table 4). This finding further supports the importance of the using clean aggregates for water quality improvement through PICP.

Table 4. Clean water test result.

\begin{tabular}{ccc}
\hline & Concentration in Tap Water & Mean Concentration in the Effluent \\
\hline TSS & $0(\mathrm{~g})$ & $13.01(\mathrm{~g})$ \\
Ammonia-nitrogen & $0.01(\mathrm{mg} / \mathrm{L})$ & $0.13(\mathrm{mg} / \mathrm{L})$ \\
Orthophosphate-phosphorus & $0(\mathrm{mg} / \mathrm{L})$ & $0.47(\mathrm{mg} / \mathrm{L})$ \\
Nitrate-nitrogen & $0(\mathrm{mg} / \mathrm{L})$ & $7.3(\mathrm{mg} / \mathrm{L})$ \\
\hline
\end{tabular}

\subsection{Lab Test Results}

During the course of Phase 1, it became apparent that the influent pollutant concentrations were not always consistent, furthermore, the use of two different fertilizer concentrations made it difficult to 
compare influent and effluent pollutant concentrations. Therefore, the samples collected during Phase 1 could only be regarded as indicative and were thus discarded in favour of those obtained from the Phase 2 testing which are now described.

\subsubsection{Ammonia-Nitrogen}

Figures 6 and 7 present the ammonia-nitrogen concentrations in the form of box-and-whisker plots and their variation over time respectively for the discharge from each of the cells upon application of the synthetic stormwater 'influent' with an ammonia-nitrogen concentration of $2 \mathrm{mg} / \mathrm{L}$. The Efficiency ratio (ER) method was used to calculate the removal efficiency for each pollutant to assess the treatment performance for the different design of the PICP cells (Equation (1)).

$$
\text { Removal } \%=\frac{\text { Mean inlet EMC }- \text { Mean outlet EMC }}{\text { Mean inlet EMC }} .
$$

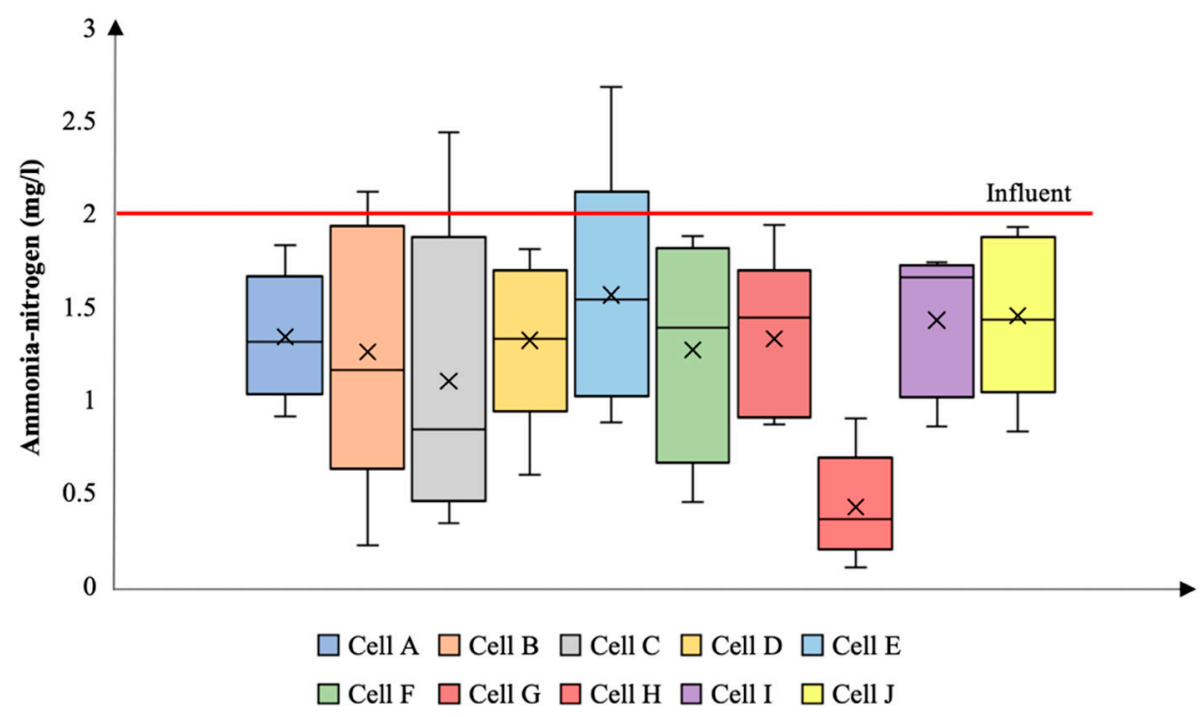

Figure 6. Concentration of ammonia-nitrogen. Sample number $=5$; box plots show medians and 25th and 75th percentiles; whiskers represent the 10th and 90th percentiles.

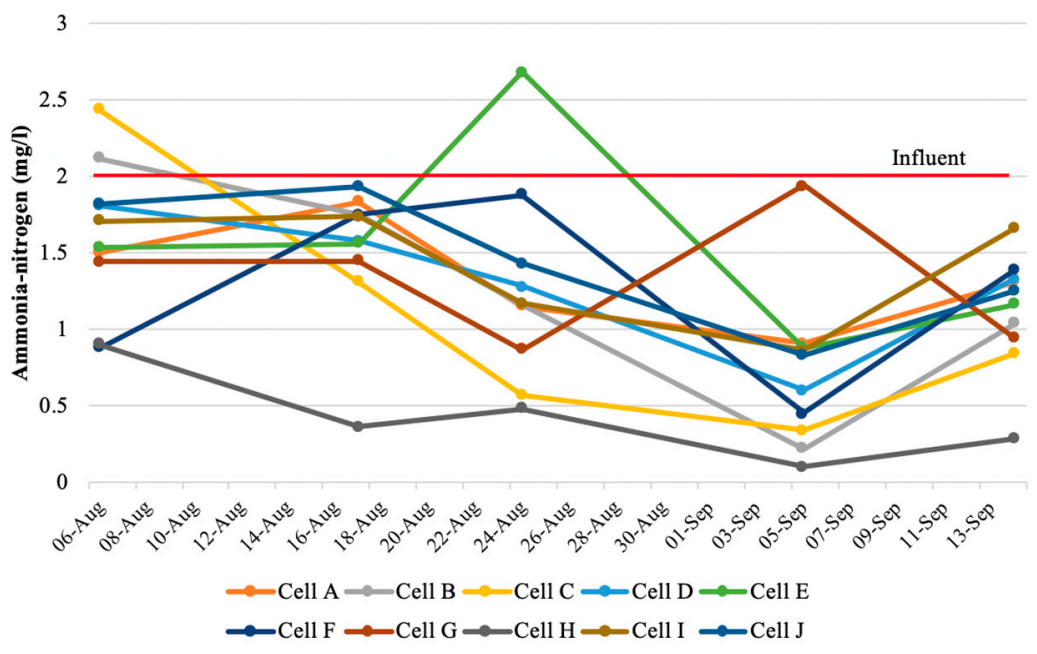

Figure 7. Variation in the ammonia-nitrogen concentrations with time.

The mean removal efficiency for ammonia-nitrogen ranged from $27.5 \%$ to $78.7 \%$ whilst the mean ammonia-nitrogen concentration ranged from 0.1 to $2.68 \mathrm{mg} / \mathrm{L}$. The measurements indicate that the cells 
with Aquaflow ${ }^{\circledR}$ pavers showed better ammonia-nitrogen removal than the other two; the presence of a geotextile had a positive impact on the removal efficiency of ammonia-nitrogen for all cells with Fiberte ${ }^{\circledR}$ performing better than Kaytech bidim ${ }^{\circledR}$; the presence of a submerged zone (raised outlet) increased the ammonia-nitrogen removal efficiency significantly; and the cell with washed aggregates had higher ammonia-nitrogen removal efficiencies than the equivalent cell with unwashed aggregates. The majority of PICP cells showed a decreasing trend in ammonia-nitrogen concentrations over the test period. The ammonia-nitrogen concentrations, however, tended to 'bounce' back to higher values during dry periods before dropping again during the wetting periods, which could be due to dilution and/or biological action being facilitated by wet conditions.

\subsubsection{Nitrite-Nitrogen}

Figures 8 and 9 present the mean nitrite-nitrogen concentrations in the form of box-and-whisker plots and their variation with time respectively for the discharge from each of the cells upon application of the synthetic stormwater 'influent'. Given that there was no nitrite-nitrogen in the influent, this could only have come about from the oxidation of ammonia to nitrite and nitrate, or from within the PICP structure itself. The mean nitrite-nitrogen addition for all ten cells ranged from 4 to $20.2 \%$ whilst the mean nitrite-nitrogen concentrations measured from all cells ranged from 0 to $0.43 \mathrm{mg} / \mathrm{L}$. The measurements indicate that the cells with exposed pavers had less nitrite-nitrogen addition than the Aquaflow ${ }^{\circledR}$ and Permealock ${ }^{\circledR}$ pavers; cells with a geotextile had less nitrite-nitrogen addition for most cells except for Cell I; the cell with a Fibertex ${ }^{\circledR}$ geotextile had similar nitrite-nitrogen addition to Kaytech bidim ${ }^{\circledR}$ geotextile; the presence of a submerged zone (raised outlet) had less nitrite-nitrogen addition than in those without, but the use of washed or unwashed aggregates did not appear to have any impact. The concentrations of the nitrites-nitrogen from all cells fluctuated throughout the testing period which may be related to the intermittent wet and dry periods, but further investigation is needed to confirm this.

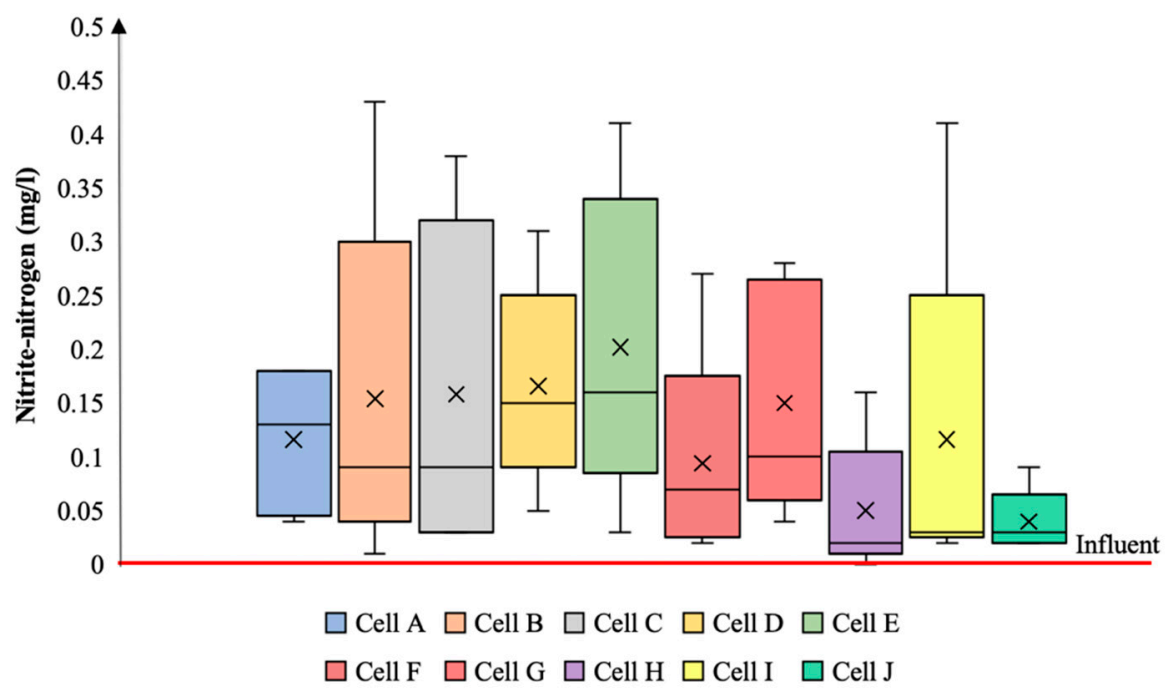

Figure 8. Concentration of nitrite-nitrogen. Sample number $=5$; box plots show medians and 25th and 75th percentiles; whiskers represent the 10th and 90th percentiles.

\subsubsection{Nitrate-Nitrogen}

Figures 10 and 11 present the mean nitrate-nitrogen concentrations in the form of box-and-whisker plots and their variation with time, respectively, for the discharge from each of the cells upon application of the synthetic stormwater 'influent' with a nitrate-nitrogen concentration of $0.6 \mathrm{mg} / \mathrm{L}$. It was found that the nitrate-nitrogen concentrations decreased significantly through the entire testing period, although most were greater than in the influent. 


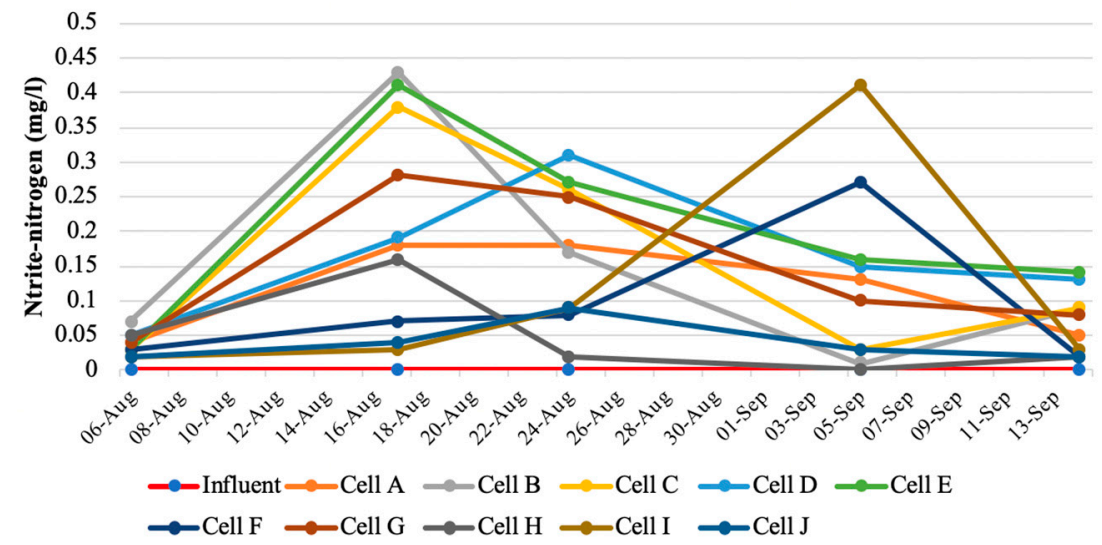

Figure 9. Variation in the nitrite-nitrogen concentrations with time.

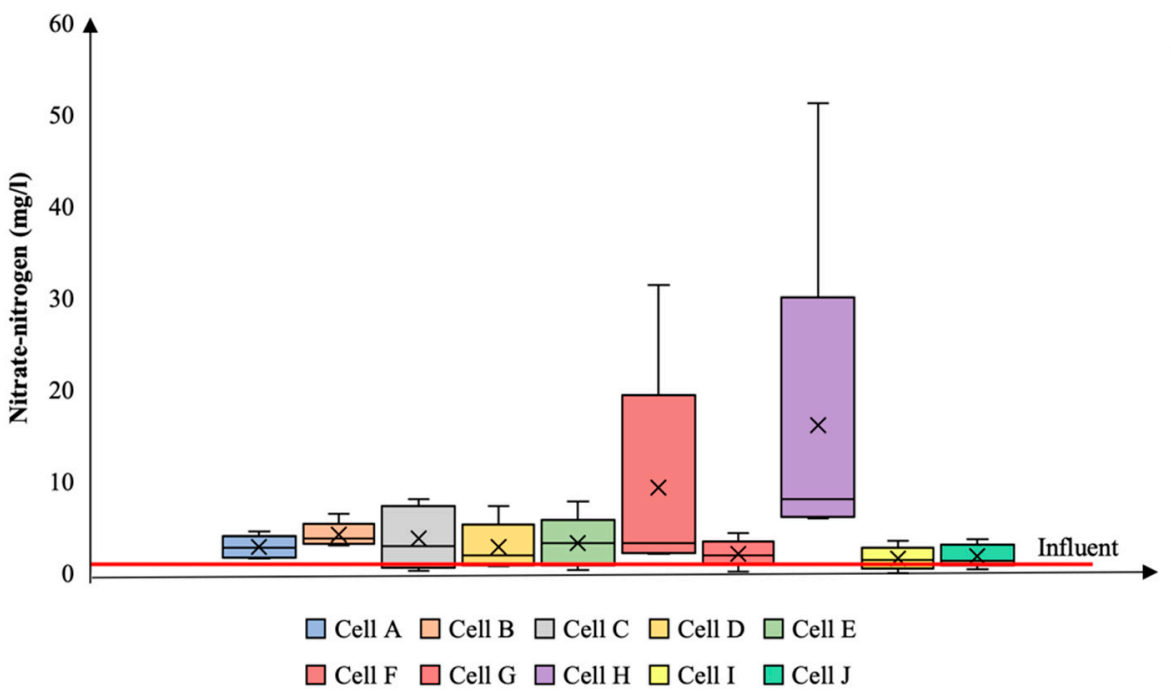

Figure 10. Concentration of nitrate-nitrogen. Sample number $=5$; box plots show medians and 25th and 75 th percentiles; whiskers represent the 10th and 90th percentiles.

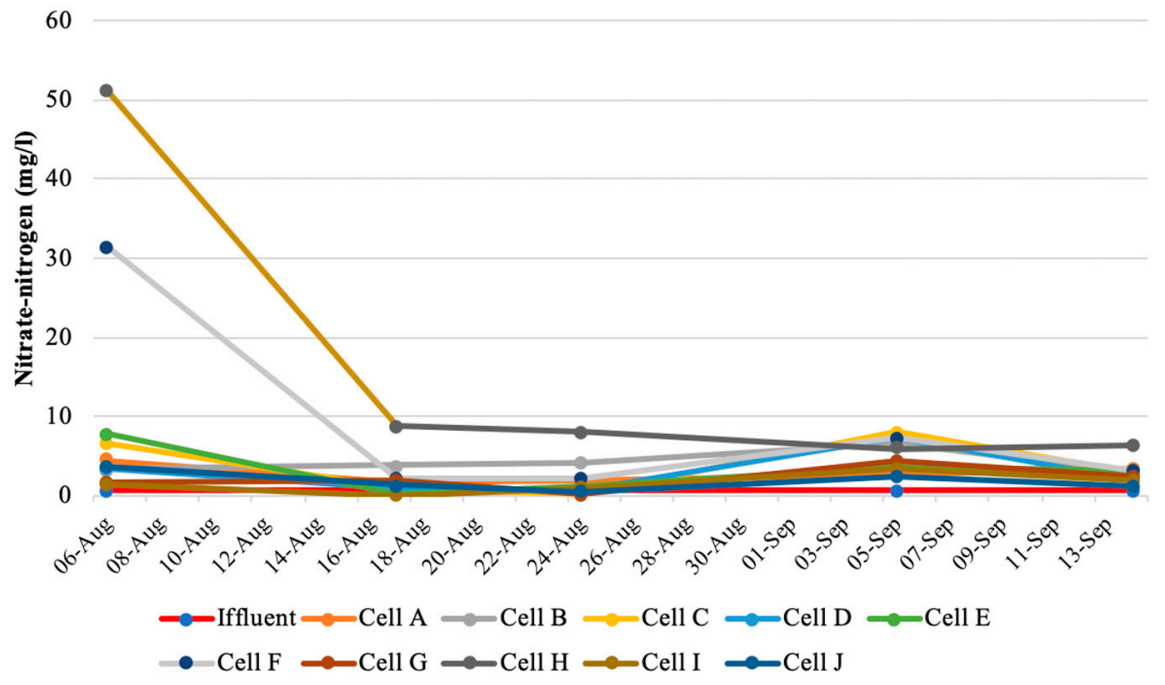

Figure 11. Variation in the nitrate-nitrogen concentrations with time.

The mean nitrate addition for all ten cells ranged from $160 \%$ to $2580 \%$, whilst the mean nitrate-nitrogen concentration from all cells ranged from 0 to $51.3 \mathrm{mg} / \mathrm{L}$. The cells with exposed pavers added less 
nitrate-nitrogen than those with Aquaflow ${ }^{\circledR}$ or Permealock ${ }^{\circledR}$ pavers. The cells with Kaytech bidim ${ }^{\circledR}$ geotextile added less nitrate-nitrogen than the cells with Fibertex ${ }^{\circledR}$ geotextile. The presence of a geotextile resulted in higher nitrate-nitrogen addition in most cells. The presence of a submerged zone (raised outlet) added significant amounts of nitrate-nitrogen compared with the ones without. This may be attributed to the nitrification process in which ammonia is transformed to nitrate-further supported by the high ammonia removal rate in the same cell. The nitrate-nitrogen concentrations from the cells with unwashed aggregates were higher than those from the cells with washed aggregates, which suggests that unwashed aggregates introduce nitrate-nitrogen into PICP.

The removal of nitrogen is highly dependent on the nitrogen species as well as the oxygen conditions (aerobic, anaerobic, or anoxic) within the PICP. Ammonia is transformed into nitrate-nitrogen under aerobic conditions by nitrifying bacteria, or it can be adsorbed to negatively charged sites on the filter material. Anoxic conditions and an electron donor-such as carbon-are the two essential factors necessary for denitrification in the treatment systems [43-45].

\subsubsection{Orthophosphate-Phosphorus}

Figures 12 and 13 illustrate the mean orthophosphate-phosphorus concentration in the form of box-and-whisker plots and their variation with time respectively for the discharge from each of the cells upon application of the synthetic stormwater 'influent' with an orthophosphate-phosphorus concentration of $0.8 \mathrm{mg} / \mathrm{L}$. The mean removal efficiency for orthophosphate-phosphorus for all ten cells ranged from $-37 \%$ to $11 \%$, and the mean orthophosphate-phosphorus concentration ranged from 0.53 to $1.39 \mathrm{mg} / \mathrm{L}$. From the measurements, it is hard to say whether the presence of a geotextile had a positive impact on the removal efficiency of orthophosphate-phosphorus. The cells with Aquaflow ${ }^{\circledR}$ pavers showed better orthophosphate-phosphorus reduction than the Permealock ${ }^{\circledR}$ or exposed pavers. The cells with a Kaytech bidim ${ }^{\circledR}$ geotextile performed better than those with a Fibertex ${ }^{\circledR}$ geotextile. The presence of a submerged zone (raised outlet) added a significant amount of orthophosphate-phosphorus compared with those cells without. This could be because phosphate is adsorbed by sediments within the submerged saturated zone that are later released under anoxic conditions. Furthermore, the low oxygen condition in the submerged zone may cause the mobilization and export of previously particle-bound phosphate from the filter material $[46,47]$. The use of unwashed aggregates introduced more orthophosphate-phosphorus into the system. Nevertheless, most of the cells show a decreasing trend in orthophosphate-phosphorus concentration. The orthophosphate-phosphorus concentrations, however, tend to 'bounce' back to higher concentrations during dry periods between tests before dropping again during the wet periods, which is likely due to the dilution effect and/or biological action being facilitated by wet conditions. More data is needed to fully understand the impact of the dry and wet periods on orthophosphate-phosphorus concentrations in PICP.

\subsubsection{Electroconductivity (EC)}

The electrical conductivity drops overall during wet periods, whilst dry periods see a rise (Figure 14). The drop in wet periods could be because the ions present in the PICP are being diluted or else the bacterial colonies are only active during wet periods, thereby reducing the ionic strength and thus a decrease in the EC. Conversely, during dry periods, the ions could become more concentrated and/or the bacterial colonies could be going into 'hibernation' and becoming inactive, resulting in an increase in EC when stormwater is added. This requires further investigation. The mean EC from all ten PICP cells ranges from 223 to $478 \mu \mathrm{S} / \mathrm{cm}$ compared with an influent EC of $126 \mu \mathrm{S} / \mathrm{cm}$. Significantly, the EC from all PICP cells was higher than the influent, which suggests that the aggregates in the PICP introduced more ions to the effluent. 


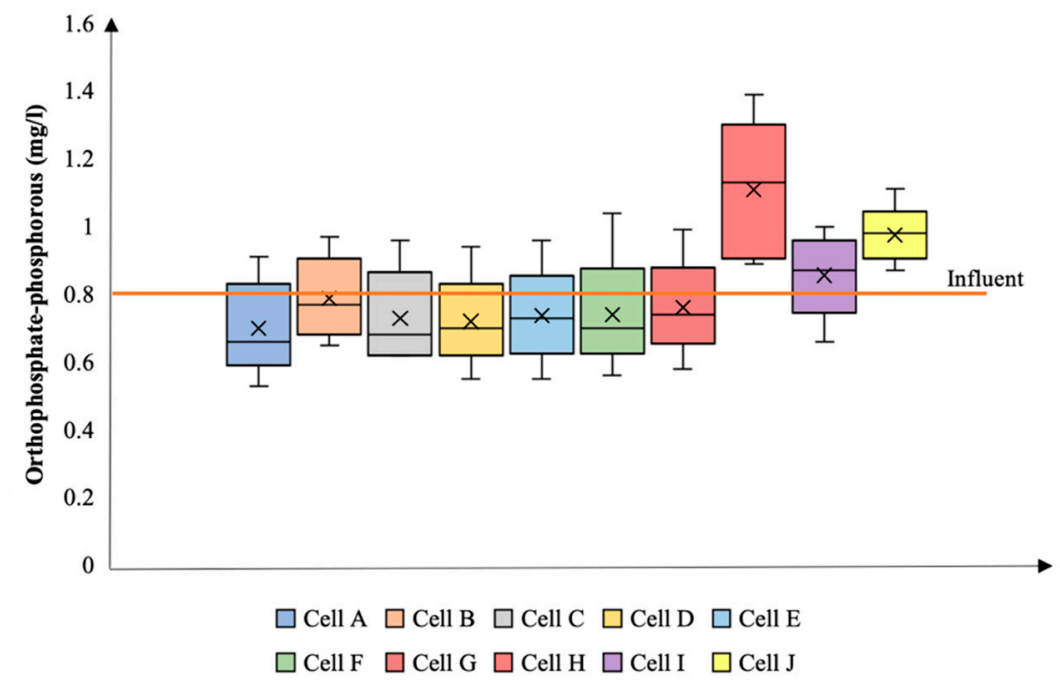

Figure 12. Concentration of orthophosphate-phosphorus. Sample number $=5$; box plots show medians and 25th and 75th percentiles; whiskers represent the 10th and 90th percentiles.

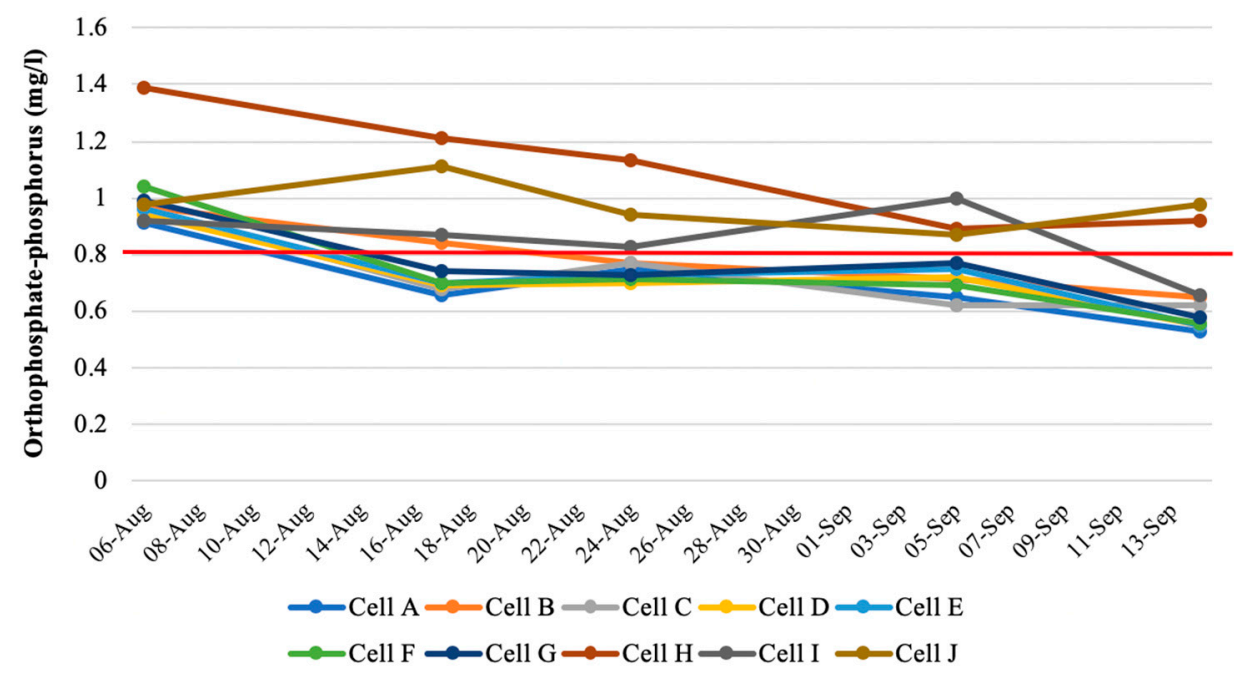

Figure 13. Variation in the orthophosphate-phosphorus concentrations with time.

\subsection{6. $\mathrm{pH}$}

The $\mathrm{pH}$ of the discharge from each of the cells ranged between 7.71 and 8.52 compared with 8.3 for the influent. Except for the two cells capped with exposed aggregate pavers, the effluent from the $\mathrm{PICP}$ cells had lower $\mathrm{pH}$ than for the influent. This could be because the exposed aggregate pavers used a higher cement/water ratio in their manufacture than for the other two types. Popovics [48] and Jennifer et al. [49] indicate that high cement/water ratios tend to result in the leaching of calcium hydroxide, thus increasing the $\mathrm{pH}$.

The measured $\mathrm{pH}$ values fall within the range of 7.6-8.8 for growth of Nitrosomonas and Nitrobacter which are the bacteria responsible for nitrifying ammonia to nitrite and then to nitrate. The relationship between the $\mathrm{pH}$ and nitrate-nitrogen concentrations in the different cells is presented in Figure 15. It can be clearly seen that the PICP cell with the highest $\mathrm{pH}$ produced the lowest nitrate-nitrogen concentration in the effluent whilst the PICP cell with the lowest $\mathrm{pH}$ produced the highest. This corresponds with the findings of Collins et al. [14]; Drake at al. [30], and Brown and Borst [13]. 


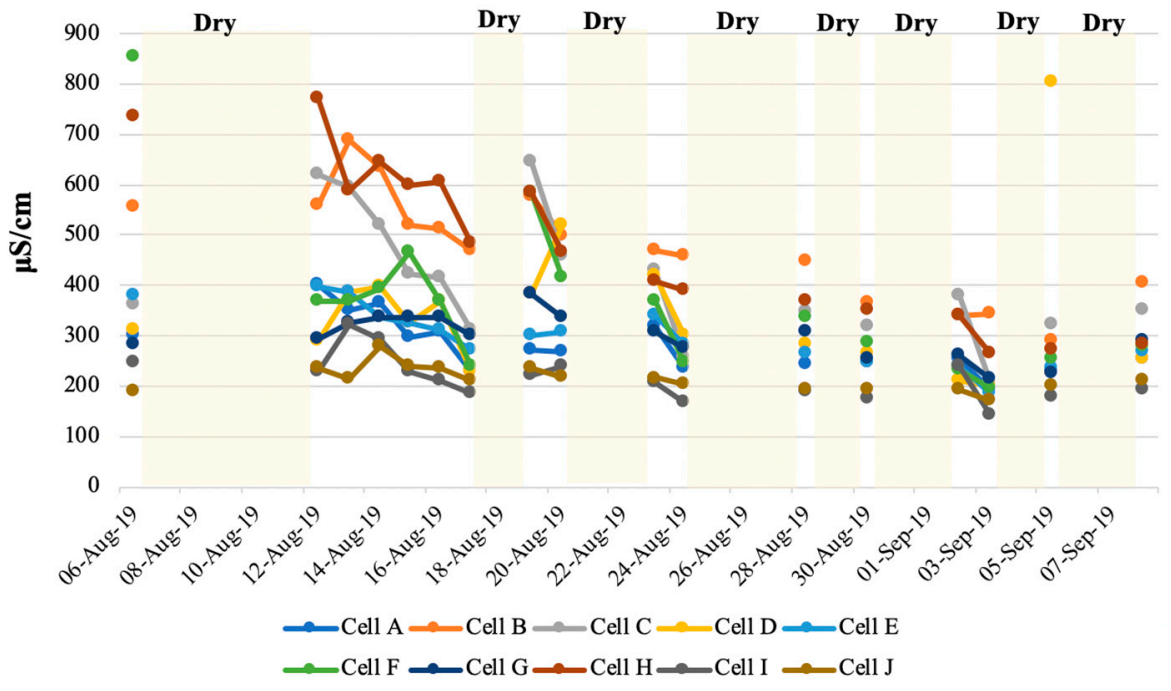

Figure 14. Variation of electroconductivity (EC) with time.

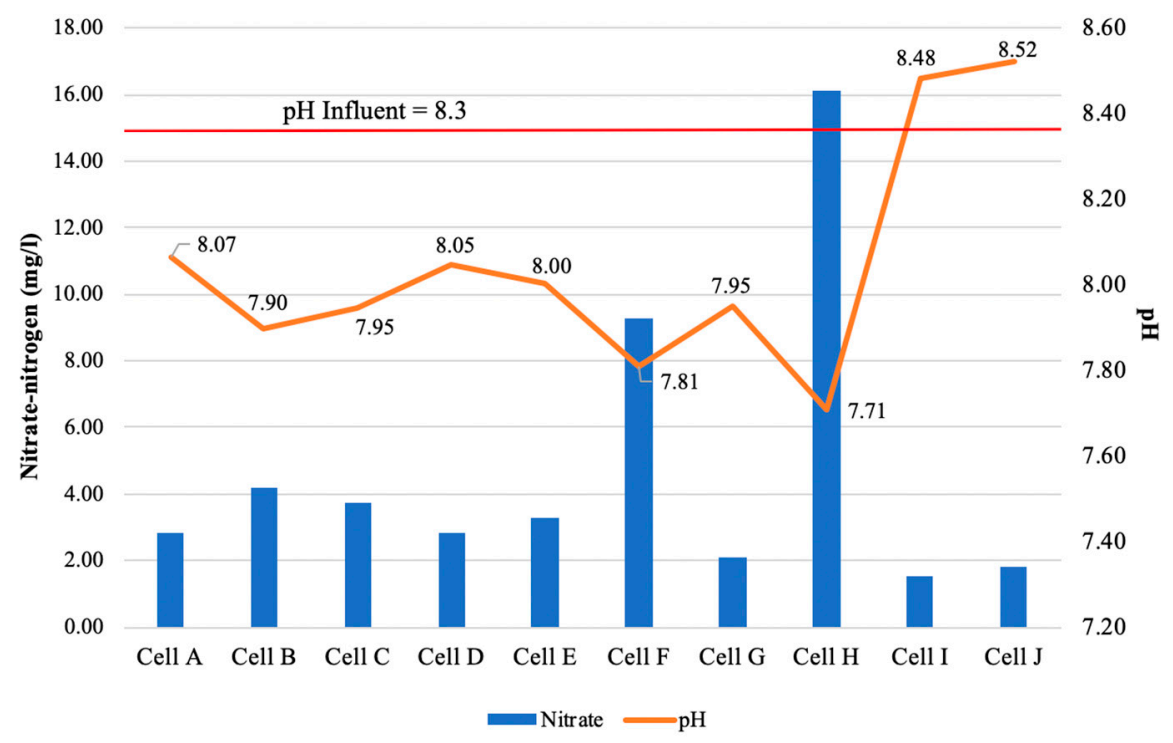

Figure 15. Relationship between $\mathrm{pH}$ and nitrate-nitrogen concentration.

\subsection{Field Test Results}

\subsubsection{Total Suspended Solids (TSS)}

As expected, the surface runoff from the impermeable NEB-I section had the highest measured TSS concentrations-possibly emanating from the surrounding trees and litter on the road. The other two sections had much lower TSS discharges which demonstrates the excellent TSS removal efficiencies from PICP systems. NEB-A (with geotextile) discharged lower TSS than NEB-B (without geotextile)-85.5\% versus $77.3 \%$ of influent. This is presumably because the presence of geotextile prevents fine particles from flowing downward into the aggregate layers.

\subsubsection{Ammonia-Nitrogen}

The surface runoff had a higher ammonia-nitrogen concentration than both PICP sections, which demonstrates the PICP ammonia-nitrogen removal ability. NEB-A (with geotextile) discharged less ammonia-nitrogen than NEB-B (without geotextile) $-62.1 \%$ versus $37.9 \%$ of influent. This suggests that the presence of geotextile has a positive impact on ammonia-nitrogen removal. 


\subsubsection{Nitrate-Nitrogen}

NEB-A (with geotextile) discharged higher nitrate-nitrogen concentrations than NEB-B (without geotextile) $-168 \%$ versus $138.7 \%$ of influent. This suggests that the presence of a geotextile results in higher nitrate-nitrogen which corresponds to what was observed in the laboratory experiments. It also shows that PICP does not promote nitrate-nitrogen removal as originally thought. The $\mathrm{pH}$ range of 7.65-8.32 falls within the range of 7.6-8.8 for growth of Nitrosomonas and Nitrobacter which are the bacteria responsible for nitrifying ammonium to nitrite and then to nitrate. NEB-A (with geotextile) with the higher $\mathrm{pH}$ values produced lower nitrate-nitrogen concentrations than NEB-B (without geotextile). This corresponds with the laboratory experiments.

\subsubsection{Orthophosphate-Phosphorus}

The surface runoff had the highest mean orthophosphate-phosphorus concentrations of all three test areas, which indicates that PICP has an orthophosphate-phosphorus removal ability. NEB-A (with geotextile) and NEB-B (without geotextile) had similar orthophosphate-phosphorus concentrations with NEB-A (with geotextile) being slightly lower than NEB-B (without geotextile)-50.9\% versus $49.1 \%$. It is thus hard to comment on whether the presence of a geotextile had an impact on the orthophosphate-phosphorus removal in the field study.

\section{Conclusions}

This investigation examined the relative impact of different designs of PICP (different types of pavers, the presence of absence of geotextile, the use of washed and unwashed aggregates, and incorporation of a permanently wet zone) on water quality improvement.

The removal efficiencies of ammonia-nitrogen from synthetic stormwater ranged from $27.5 \%$ to $78.7 \%$. It was found that the cells with Aquaflow ${ }^{\circledR}$ pavers had higher ammonia-nitrogen removal efficiencies than the other two types of pavers; the cell with an Inbitex ${ }^{\circledR}$ geotextile present had a higher ammonia-nitrogen removal efficiency than the one without; the cells with Fibertex ${ }^{\circledR}$ geotextile had higher ammonia-nitrogen removal efficiencies than those with Kaytech bidim ${ }^{\circledR}$ geotextile; the cells with washed aggregates had higher ammonia-nitrogen removal efficiencies than the ones with unwashed aggregates; and the cell with the raised outlet (creating a 'sump' in the underlying stone aggregate) had the highest ammonia-nitrogen removal efficiency of all.

All the experimental cells appeared to add significant quantities of nitrate-nitrogen with the nitrate-nitrogen addition ranging from $160 \%$ to $2580 \%$, which is probably due to the nitrification process of ammonia to nitrate. The cells with exposed pavers produced less nitrite-nitrogen and nitrate-nitrogen addition than the other two types of pavers; the cell with the raised outlet produced the most nitrate-nitrogen. It was also found that the presence of geotextile has a negative impact on the nitrate-nitrogen removal efficiencies. When the $\mathrm{pH}$ is within the optimum range of 7.6-8.8 for the growth of nitrifying bacteria, the nitrification process will result in the reduction of ammonia-nitrogen concentration, and thus, the increase in nitrate-nitrogen concentration. Lower $\mathrm{pH}$ results in higher nitrate-nitrogen concentrations.

The removal efficiencies for orthophosphate-phosphorus ranged from $-37 \%$ to $11 \%$ compared with the mean of $47.7 \%$ removal rate of orthophosphate-phosphorus in other studies. The cells with Aquaflow ${ }^{\circledR}$ pavers had higher orthophosphate-phosphorus removal efficiencies than the other two types of pavers; the presence of a geotextile resulted in a higher orthophosphate-phosphorus removal efficiencies than those without; the cell with Kaytech bidim ${ }^{\circledR}$ geotextile had a higher orthophosphate-phosphorus removal efficiency than the one with Fibertex ${ }^{\circledR}$ geotextile; the cells with washed aggregates had a higher orthophosphate-phosphorus removal efficiencies than the ones with unwashed aggregates. The cell with the raised outlet had the lowest orthophosphate-phosphorus removal efficiency of all which might be due to the fine particles being slowly washed through the PPS and desorption due to the lack of useful adsorption sites. 
The electrical conductivity strongly depends on the length of the periods between rainfall 'seasons'; it decreases rapidly during wet periods and increases slowly during the dry periods. This could be because the ions being measured are diluted during wet periods and concentrated during dry periods. Alternatively, the various bacteria in the cells could be more active during wet periods compared with dry periods and this might have an impact on the ionic strength. This requires further investigation.

Overall, it may be concluded that whilst PICP is effective in removing ammonia-nitrogen, it is at the expense of increased nitrite-nitrogen and nitrate-nitrogen. Further research is required on whether the creation of an anoxic zone coupled with introduction of a suitable electron donor to the PICP could address this shortcoming.

Author Contributions: B.K.L. constructed the PICP cells with the help of various other students and laboratory staff, carried out the experiments, collected the data, analysed the results, wrote the first draft of the paper and collaborated with N.P.A. on its improvement. N.P.A. conceived the project, provided the funding, offered guidance on the undertaking of the research, and did considerable editorial work on the paper. All authors have read and agreed to the published version of the manuscript.

Funding: This research was funded entirely from savings that Neil Armitage has made on previous research projects.

Conflicts of Interest: The authors declare no conflict of interest.

\section{References}

1. Cronshey, R. Urban Hydrology for Small Watersheds, 2nd ed.; US Department of Agriculture: Washington, DC, USA, 1986.

2. Finkenbine, J.; Atwater, J.; Mavinic, D. Stream health after urbanization. J. Am. Water Resour. Assoc. 2000, 36, 1149-1160. [CrossRef]

3. Armitage, N.; Vice, M.; Fisher-Jeffes, L.; Winter, K.; Spiegel, A.; Dunstan, J. South African Guidelines for Sustainable Drainage Systems; Water Research Commission: Pretoria, South Africa, 2013; p. 135.

4. Maheshwari, B.; Singh, V.P.; Thoradeniya, B. (Eds.) Balanced Urban Development: Options and Strategies for Liveable Cities; Springer: Berlin, Germany, 2016; Volume 72.

5. Brunetti, G.; Šimůnek, J.; Piro, P. A comprehensive numerical analysis of the hydraulic behavior of a permeable pavement. J. Hydrol. 2016, 540, 1146-1161. [CrossRef]

6. Pratt, C.; Newman, A.; Bond, P. Mineral Oil Bio-Degradation within a Permeable Pavement: Long Term Observations. Water Sci. Technol. 1999, 39, 103-109. [CrossRef]

7. Myers, B.; Beecham, S.; Van Leeuwen, J.A. Water quality with storage in permeable pavement basecourse. Proc. Inst. Civ. Eng. Water Manag. 2011, 164, 361-372. [CrossRef]

8. Lucke, T.; Beecham, S. Field investigation of clogging in a permeable pavement system. Build. Res. Inf. 2011, 39, 603-615. [CrossRef]

9. Mullaney, J.; Lucke, T. Practical review of pervious pavement designs. CLEAN Soil Air Water 2013, 42, 111-124. [CrossRef]

10. Eisenberg, B.; Lindow, K.C.; Smith, D.R. (Eds.) Permeable Pavements; American Society of Civil Engineers: Reston, VA, USA, 2015.

11. Pratt, C.J.; Mantle, J.; Schofield, P. UK research into the performance of permeable pavement, reservoir structures in controlling stormwater discharge quantity and quality. Water Sci. Technol. 1995, 32, 63-69. [CrossRef]

12. Rowe, A.; Borst, M.; O'Connor, T. The Effects of Urbanization on Groundwater: An Engineering Case-based Approach for Sustainable Developmeny. In Environmental Effects of Pervious Pavement as a Low Impact Development Installation in Urban Regions; ASCE: Reston, VA, USA, 2010; pp. 344-366.

13. Brown, R.A.; Borst, M. Nutrient infiltrate concentrations from three permeable pavement types. J. Environ. Manag. 2015, 164, 74-85. [CrossRef]

14. Collins, K.A.; Hunt, W.F.; Hathaway, J.M. Side-by-Side Comparison of Nitrogen Species Removal for Four Types of Permeable Pavement and Standard Asphalt in Eastern North Carolina. J. Hydrol. Eng. 2010, 15, 512-521. [CrossRef]

15. Drake, J.A.P. Performance and Operation of Partial Infiltration Permeable Pavement Systems in the Ontario Climate. Ph.D. Thesis, University of Guelph, Guelph, ON, Canada, 2013. 
16. Huang, J.; He, J.; Valeo, C.; Chu, A. Temporal evolution modeling of hydraulic and water quality performance of permeable pavements. J. Hydrol. 2016, 533, 15-27. [CrossRef]

17. Tota-Maharaj, K.; Scholz, M. Efficiency of Permeable Pavement Systems for the Removal of Urban Runoff Pollutants Under Varying Environmental Conditions. Environ. Prog. Sustain. Energy 2010, 29, 358-369. [CrossRef]

18. Biggs, B. The Impact of Unwashed Aggregate on the Quality of Water Emanating from Permeable Pavements. Master's Thesis, University of Cape Town, Cape Town, South Africa, 2016.

19. Boving., T.; Stolt, M.; Augenstern, J. Investigation of the University of Rhode Island, Kingston, RI, porous pavement parking lot and its impact on subsurface water quality. In Proceedings of the 33 Annual Meeting. International Association of Hydrologists, Zacatecas, Mexico, 7-10 November 2004.

20. Newman, A.P.; Pratt, C.J.; Coupe, S.J.; Cresswell, N. Oil bio-degradation in permeable pavements by microbial communities. Water Sci. Technol. 2002, 45, 51-56. [CrossRef] [PubMed]

21. Nnadi, E.O.; Newman, A.P.; Coupe, S.J. Geotextile incorporated permeable pavement system as potential source of irrigation water: Effects of re-used water on the soil, plant growth and development. CLEAN Soil Air Water 2014, 42, 125-132. [CrossRef]

22. Legret, M.; Colandini, V. Effects of a porous pavement with reservoir structure on runoff water: Water quality and fate of heavy metals. Water Sci. Technol. 1999, 39, 111-117. [CrossRef]

23. Pagotto, C.; Legret, M.; Le Cloirec, P. Comparison of the hydraulic behaviour and the quality of highway runoff water according to the type of pavement. Water Res. 2000, 34, 4446-4454. [CrossRef]

24. Bean, E.Z.; Hunt, W.F.; Bidelspach, D. Evaluation of Four Permeable Pavement Sites in Eastern North Carolina for Runoff Reduction and Water Quality Impacts. J. Irrig. Drain. Eng. 2007, 133, 583-592. [CrossRef]

25. Brown, C.; Chu, A.; Van D., B.; Valeo, C. Characteristics of sediment removal in two types of permeable pavement. Water Qual. Res. J. 2009, 44, 59-70. [CrossRef]

26. Charlesworth, S.M.; Beddow, J.; Nandi, E.O. The fate of pollutants in porous asphalt pavements, laboratory experiments to investigate their potential to impact environmental health. Int. J. Environ. Res. Public Health 2017, 14, 666. [CrossRef]

27. Ball, J.E.; Rankin, K. The hydrological performance of a permeable pavement. Urban Water J. 2010, 7, 79-90. [CrossRef]

28. Huang, J.; Valeo, C.; He, J.; Chu, A. Winter Performance of Inter-Locking Pavers—Stormwater Quantity and Quality. Water 2012, 4, 995-1008. [CrossRef]

29. Wiesman, U. Biological nitrogen removal from wastewater. In Biotechnics/Wastewater. Advances in Biochemical Engineering/Biotechnology; Springer: Berlin/Heidelberg, Germany, 1994; Volume 51, pp. 113-154.

30. Collins, K.A.; Lawrence, T.J.; Stander, E.K.; Jontos, R.J.; Kaushai, S.S.; Newcomer, T.A.; Grimm, N.B.; Ekberg, M.L.C. Opportunities and challenges for managing nitrogen in urban stormwater: A review and synthesis. Ecol. Eng. 2010, 36, 1507-1519. [CrossRef]

31. Drake, J.; Bradford, A.; Van Seters, T. Stormwater quality of spring-summer-fall effluent from three partial-infiltration permeable pavement systems and conventional asphalt pavement. J. Environ. Manag. 2014, 139, 69-79. [CrossRef] [PubMed]

32. Roseen, R.M.; Ballestero, T.P.; Houle, J.J.; Avellaneda, P.; Briggs, J.; Fowler, G.; Wildey, R. Seasonal performance variations for storm-water management systems in cold climate conditions. J. Environ. Eng. 2009, 135, 128-137. [CrossRef]

33. Mullaney, J.; Jefferies, C.; Mackinnon, E. The performance of block paving with and without a geotextile in the sub-base. In Proceedings of the 12th International Conference on Urban Drainage, Porto Alegre, Brazil, 11-16 September 2011; Volume 1115.

34. Zhao, Y.; Zhou, S.; Zhao, C.; Valeo, C. The influence of geotextile type and position in a porous asphalt pavement system on $\mathrm{Pb}$ (II) removal from stormwater. Water 2018, 10, 1205. [CrossRef]

35. Hanson-Formpave Formpave Product Directory. Hanson Heidelberg Cement Group. 2010. Available online: http://www.formpave.co.uk (accessed on 8 July 2017).

36. C.E.L Paving Products. Permealock. Available online: http://celpaving.co.za/permealock/ (accessed on 8 July 2017).

37. Fibertex. Fibertex Geotextiles Product Data Sheet: Polypropylene Needlepunched Geotextiles; Fibertex South Africa (Pty) Ltd.: Hammarsdale, South Africa, 2012; Available online: http://www.fibertex.co.za. (accessed on 10 August 2017). 
38. Kaytech. "A" Range Nonwoven, Needle Punched, Continuous Filament, Polyester Geotextile Manufactured in RSA by Kaytech Atlantis, and ISO 9001:2008 Accredited Facility (Registration No: LS1176) Reference No: DS FLTR 0587-02/2015 Rev 3, 2015. Kaytech Engineered Fabrics Technical Data Sheet. Available online: https://kaytech.co.za/wp-content/uploads/2017/05/bidim-Data-Sheet-DS-FLTR-0587-02_2015-Rev3-.pdf (accessed on 15 June 2020).

39. Terram. Inbitex Geotextile Product Data Sheet. Issue: 01. Date: 11 July 2012. TERRAM. Available online: https://www.terram.com/request-file.php?fid=293 (accessed on 15 June 2020).

40. ASTM. C1781 Standard Test Method for Surface Infiltration Rate of Permeable Uunit Pavement Systems; ASTM International: West Conshohocken, PA, USA, 2013.

41. US EPA. Method 160.2: Total Suspended Solids; US EPA: Washington, DC, USA, 1999.

42. Thermo Scientific ${ }^{\mathrm{TM}}$. Gallery ${ }^{\mathrm{TM}}$ Discrete Analyzer. Available online: https://www.thermofisher.com/order/ catalog/product/98610001\#/98610001 (accessed on 15 November 2019).

43. Subramaniam, D.; Egodawatta, P.; Gallage, C.; Mather, P.; Rajapakse, J. Significance of Drying Periods on Nitrate Removal in Experimental Biofilters. J. Water Manag. Model. 2014, 1-6. [CrossRef]

44. Cheremisinoff, N. Handbook of Water and Wastewater Treatment Technologies; Butterworth-Heinemann: Woburn, MA, USA, 2002.

45. Von Sperling, M.; de Lemos Chernicharo, C.A. Biological Wastewater Treatment in Warm Climate Regions; IWA Publishing: London, UK, 2005.

46. Correll, D.L. Phosphorus: A rate limiting nutrient in surface waters. Poult. Sci. 1999, 78, 674-682. [CrossRef]

47. Zinger, Y.; Blecken, G.T.; Fletcher, T.D.; Viklander, M.; Deletić, A. Optimising nitrogen removal in existing stormwater biofilters: Benefits and tradeoffs of a retrofitted saturated zone. Ecol. Eng. 2013, 51, 75-82. [CrossRef]

48. Popovics, S. Analysis of concrete strength versus water-cement ratio relationship. Mater. J. 1990, 87, 17-529.

49. Grubb, J.A.; Limaye, H.S.; Kakade, A.M. Testing pH of concrete-Need for a standard procedure. Concr. Int. 2007, 29, 78-83.

(C) 2020 by the authors. Licensee MDPI, Basel, Switzerland. This article is an open access article distributed under the terms and conditions of the Creative Commons Attribution (CC BY) license (http://creativecommons.org/licenses/by/4.0/). 